\title{
RELIGION, STATE AND HUMAN RIGHTS: Negotiating Accommodation Limits in the Constitutional Court
}

\author{
Rumadi \\ Faculty of Sharia and Law, State Islamic University (UIN) Syarif Hidayatullah Jakarta, Indonesia \\ J. Ir. H. Djuanda No.95 Ciputat 15412, Jakarta \\ E-mail: rumadi@uinjkt.ac.id
}

\begin{abstract}
One of crucial issue in Muslim countries, such as Indonesia, is relation between religion and the state. Even though Pancasila and the 1945 Constitution were claimed final, but it did not necessarily mean that position of religion, state and human rights is final and clear. The negotiation between religion, state and human rights not only on political forum like at The House of Representative, but also in Constitutional Court session. There are debates and opinion contestations. The problem is what is the politics of law accommodation towards religious aspirations, which the Constitutional Court has built through its decisions and arguments? Through analysis on two issues: 1) freedom of religion and belief; and 2) marriage law, this article argues that Constitutional Court's decision, especially relation between religion, state and human rights not only based on law consideration, but also on non-law consideration. Regarding private law, the Constitutional Court opened a fairly wide accommodation, so that more religious aspects would be accommodated by the state even with limited reforms. The limit of accommodation is an Islamic criminal law that cannot be made exclusively for Muslims. The accommodation of Islamic criminal law is only possible if the norms are incorporated into the national criminal law through a process of rational objectification. Based on this argument, continuous negotiation and contestation between religion, state and human rights will go on since Indonesia is not a religious state, which is based only on one religion, nor a secular state, which does not consider religion at all.
\end{abstract}

Keywords: Constitutional Court; Human Rights; beliefs; blasphemy; marriage law.

\begin{abstract}
Abstrak: Salah satu isu krusial di negara Muslim, tidak terkecuali Indonesia, adalah relasi agama dan negara. Meskipun Pancasila dan Undang-Undang Dasar 1945 dinyatakan final, namun bukan berarti kedudukan agama, negara, dan hak asasi manusia sudah final dan jelas. Perundingan antara agama, negara dan hak asasi manusia tidak hanya di forum politik seperti di Dewan Perwakilan Daerah (DPR), tapi juga di sidang Mahkamah Konstitusi. Ada perdebatan dan kontestasi pendapat. Persoalannya, bagaimana politik akomodasi hukum terhadap aspirasi agama yang dibangun Mahkamah Konstitusi melalui putusan dan dalilnya? Melalui analisis terhadap dua isu: 1) kebebasan beragama dan berkeyakinan; dan 2) hukum perkawinan, pasal ini berpendapat bahwa putusan Mahkamah Konstitusi khususnya hubungan antara agama, negara dan hak asasi manusia tidak hanya berdasarkan pertimbangan hukum, tetapi juga pertimbangan non hukum. Terkait hukum privat, Mahkamah Konstitusi membuka akomodasi yang cukup luas, sehingga lebih banyak aspek keagamaan yang diakomodasi oleh negara meski dengan reformasi yang terbatas. Batasan akomodasi adalah hukum pidana Islam yang tidak dapat dibuat secara eksklusif untuk Muslim. Akomodasi hukum pidana Islam hanya dimungkinkan jika norma-norma tersebut dimasukkan ke dalam hukum pidana nasional melalui proses objektifikasi yang rasional. Berdasarkan argumen ini, negosiasi dan kontestasi yang terus menerus antara agama, negara dan hak asasi manusia akan terus berlangsung karena Indonesia bukanlah negara agama yang hanya didasarkan pada satu agama, bukan pula negara sekuler, yang sama sekali tidak mempertimbangkan agama.
\end{abstract}

Kata kunci: Mahkamah Konstitusi; HAM; penghayat kepercayaan; penodaan agama; hukum perkawinan.

\section{Introduction}

The decisions of the Constitutional Court related to religious issues are basically an effort to organize the position of the state, religion and human rights. The issue of the relationship between religion and the state has long been a political ideological struggle in Indonesia. Since the establishment of the state, it has always provided space for negotiation and debate. The Constitutional Court decision is an official 
interpretation of the constitution with final and binding force. The verdict of the Constitutional Court judges not only ends various different perspectives on the law and the constitution, but also affirms the political direction of law in Indonesia.

There are some decisions related to religious matters, which can be divided into several categories: First, those related to marriage issues (al-ahwâl al-syakhsiyyah) as regulated in Law no. 1 of 1974 concerning Marriage. In the case of marriage, there are several issues that are tested for constitutionality, namely the matter of regulating polygamy, ${ }^{1}$ provisions on the legality of children born outside of legal marriages, ${ }^{2}$ interfaith marriages, ${ }^{3}$ and restrictions on the age of marriage. ${ }^{4}$

Second, the matter of blasphemy as regulated in Law no. 1 / PNPS / 1965. This law has been judged twice with different touchstones. ${ }^{5}$ Third, regarding the competence of the Religious Courts as in Law no. 3 of 2006 concerning Religious Courts related to the implementation of Islamic criminal law. ${ }^{6}$ Fourth, financial and economic arrangements, the laws being tested are the Sharia Banking Law and the Zakat Management Law. ${ }^{7}$ Fifth, the status

${ }^{1}$ The verdict No. 12/PUU-V/2007 about examining UU No. 1 Tahun 1974. The articles in question are article 3 paragraph (1) and paragraph (2), article 4 paragraph (1) and (2), article 5 paragraph (1), article 9 , article 15 , article 24 related to the regulation of polygamy.

${ }^{2}$ The verdict No. 46/PUU-VIII/2010 about examining UU No. 1 Tahun 1974. The articles in question are article 2 paragraph (2) and article 43 paragraph (1) related to the legal status of children outside of wedlock

3 The verdict No. 68 / PUU-XII / 2014 about examining Article 2 paragraph (1) of Law no. 1 of 1974. This article regulates the legality of marriage that must be carried out with a partner of the mutual religion

4 The verdict No. 30-74 / PUU-XII / 2014 which tested the constitutionality of Article 7 paragraph (1) of Law no. 1 of 1974 concerning Marriage. This article regulates the minimum age of marriage for women 16 years old

5 The verdict No. 84 / PUU-X / 2012 regarding the examination of the Criminal Code and Judicial Review of Law No. 1 / PNPS / 1965 concerning the Prevention of Abuse and/ or Blasphemy of Religion; and verdict No. 140 / PUU-VII / 2009 regarding the review of Law No. 1/PNPS/1965 concerning the Prevention of Abuse and/or Blasphemy of Religion

${ }^{6}$ The verdict No. 19/ PUU-VI / 2008 regarding the review of Law no. 7 of 1989 as amended by Law no. 3 of 2006 concerning Religious Courts. The article in question is article 49 paragraph (1) related to the competence of the Religious Courts which does not include the implementation of Islamic penalties.

7 The verdict no. 86 / PUU-X / 2012 regarding the review of of believers in religious services especially the inclusion of the religion column on the identity card (KTP). ${ }^{8}$

The Constitutional Court decisions related to these religious issues, in a political perspective, can be seen as an official interpretation of the constitution on a number of religious issues within the framework of the state. The verdict of the Constitutional Court judges can end various different perspectives on the law and the constitution. Although there are parties who accept and reject the Constitutional Court's decision, it is the Constitutional Court's decision that is considered the "final word" of various differences of opinion on the interpretation of the constitution.

These decisions provided constitutional guidance on how religious and divine issues were managed. This godly state understanding has a long history in Indonesia. This is what Jeremy Menchik ${ }^{9}$ calls godly nationalism which distinguishes Indonesian nationalism from models of nationalism in other countries. Although this theory is used by Menchik to see the symptoms of intolerance in Indonesia, it is relevant to be used as an optic to observe the Constitutional Court's legal decisions. Menchik argued that religious intolerance that continues to strengthen in Indonesia is partly because the nationalism that grows and develops in Indonesia is nationalism which from the start has included aspects of divinity in it. The Constitutional Court decisions related to religious issues cannot be separated from the spirit of divine nationalism.

Law no. 23 of 2011 concerning Zakat Management. The articles in question are articles 5, 6, 7, 17, 18, 19 related to the status, duties and functions of Baznas; Verdict No. 93 / PUU-X / 2012 regarding the review of Law no. 1 of 2008 concerning Islamic Banking.

${ }^{8}$ The Constitutional Court Verdict Number 97 / PUU-XIV / 2016 related to Law No. No. 23 of 2006 concerning Population Administration which has been amended into Law no. 24 of 2013 related to the religion column for groups of believers. The judicial review submitted by groups of believers from various regions filed a request for constitutional interpretation of Article 61 paragraph (2), and canceled Article 61 paragraph (2) and Article 64 paragraph (5) of the Population Administration Law.

9 See Jeremy Menchik, Islam and Democracy in Indonesia, Tolerance without Liberalism, (Cambridge: Cambridge University Press, 2016), pp. 65-92. And see Jeremy Menchik, "Productive Intolerance: Godly Nationalism in Indonesia", Jurnal Comparative Studies in Society and History, (2014), p. 591-621. 
In Menchik's view, Godly nationalism contains several elements. First, theism, in here all citizens are obliged to adhere one of the six valid religions. This means that divine nationalism is different from religious nationalism, as exists in Israel or some Muslim countries, where only one religion is considered valid. At the same time, Indonesian citizens are not allowed to become atheists and campaign for atheism.

Second, for every religion that is recognized and considered valid, the state has the right to determine which beliefs and practices are orthodox or which deserve to be accepted as official parts of that religion. The state provides protection to the legitimate religion from acts deemed insulting to religion. Third, the State really considers the opinions of religious organizations such as Indonesian Council of Ulama (MUI), Nahdatul Ulama (NU) and Muhammadiyah in determining heterodox types of beliefs. Beliefs which were considered obsolete and deviant were automatically outside the protection of the state. The Constitutional Court's inauguration of Law no. 1 / PNPS / 1965 concerning Blasphemy of Religion, in Menchik's view, is part of an effort to strengthen this divine nationalism.

The strengthening of divine values in the management of the state does not only occur in Indonesia, but also develops in various parts of the world, this phenomenon by Ran Hirschl on Constitutional Theocracy.10 This theory is useful for reading the Constitutional Court decisions related to religious issues. Constitutionalism is a notion that places law and constitution as a means of regulating state life.11 This understanding is usually distinguished from theocracy, which places divinity as the determinant and guide of state life. Constitutionalism is in line with the spirit of democracy and the rule of law, while theocracy is considered to be against democracy because it puts sovereignty in God's hands.

However, in the practice of law in various countries, Ran actually saw a symptom where

${ }^{10}$ see Ran Hirschl tentang Constitutional Theocracy, (Harvard: Harvard University Press, 2010), p. 2010.

1 Further understanding of constitutionalism, see Jimly Asshiddiqie, Konstitusi dan Konstitusionalisme Indonesia, (Jakarta: Sinar Grafika, 2010). many countries still adhere to constitutionalism, but religion through its figures plays an important role in the management of the country. This type of state cannot be called a theocratic state, because the constitution still plays an important role. This constitutional theocracy has developed in various countries not only in Muslim-majority countries, but also non-Muslim-majority countries.

The question to be answered in this paper is what is the direction of the legal politics of state accreditation towards religious aspirations, which the Constitutional Court is developing through its decisions and arguments? This problem will be answered by examining a number of Constitutional Court decisions related to religious issues which are broadly related to two major themes, 1) the right to religion and belief, which includes the issue of blasphemy, the application of Islamic penalties and the position of believers of belief in Almighty God; 2). Decisions regard to family law which include matters of polygamy, interfaith marriage, the status of children born outside of legal marriages, and the minimum age of marriage. Departing from this, the main problem that this paper wants to answer is how the Constitutional Court puts human rights issues, especially those related to religious rights, in the legal system and its implications for the relationship between religion and the state.

\section{Method}

The main material that is the source of this paper is the Constitutional Court decisions which will be reviewed using content analysis as a method for text analysis which is commonly called qualitative content analysis. This method views data not only as a collection of events, but also views data as symbolic symptoms. By using this method, the authors see the Constitutional Court decisions and their arguments by looking at the pragmatic content analysis; semantic content analysis; and sign-vehicle analysis. With this analysis, this deaf-san provides an assessment of the direction of legal politics related to the relationship between religion and the state in Indonesia. In contrast to several previous writings which conducted a separate analysis of a number of Constitutional Court decisions, this paper will 
look at the relationship and tendencies of state accommodation law politics to religious aspirations more comprehensively by using available data. The political and legal analysis that the Constitutional Court is based on can be misleading one or two decisions.

\section{The Constitutional Court Manages Tensions on Religion, State and Human Rights 1. Freedom of Religion and Belief}

The right to have a religion and belief is one of the human rights that is categorized as a right that cannot be reduced under any circumstances (nonderogable rights). ${ }^{12}$ However, the implementation of this right still leaves many problems, both at the level of legislation and its implementation. This has been a serious problem since the beginning of Indonesian independence. The debate over the position of religion and the state by the founders of this state shows how crucial this issue is. If until now there are still a number of laws related to religious regulation which have been judicial review at the Constitutional Court, it shows that the issue of religious, state and human rights relations cannot be said to have been completely resolved.

\section{1) Adherents and Religion Column on Identity Card (KTP)}

The Constitutional Court's decision on judicial review of Law no. 23 of 2006 concerning Population Administration which has been amended into Law no. 24 of 2013 (hereinafter referred to as the Adminduk Law) related to the religion column for groups of believers of faith is one of the crucial decisions. The judicial review submitted by groups of believers from various regions submitted a request for constitutional interpretation of Article 61 paragraph (1), and invalidated Article 61 paragraph (2) and Pasa 64 paragraph (5) of the Adminduk Law.

${ }^{12}$ In fulfilling human rights, there are two terms, namely derogable and non-derogable rights. Derogable rights are types of rights that can be regulated and the fulfillment is postponed for various reasons. Meanwhile, non-derogable rights are rights whose fulfillment cannot be postponed or deferred. See further on Rumadi dkk, Buku Sumber Hak Kebebasan Beragama dan Berkeyakinan di Indonesia, (Jakarta: Wahid Foundation, 2016), pp. 109-142.
Article 61 paragraph (1) states:

"Family Card (KK) contains information regarding the $K K$ number column, full name of the head of the family and family members, NIK, gender, address, place of birth, birth date, religion, education, occupation, marital status, family relationship status, citizenship, immigration documents, parents' name".

The Petitioners propose a constitutional interpretation so that the word "religion" in the article includes belief.

As for Article 61 paragraph (2) and 64 paragraph (5) regulate the religious ID card column and the procedure for filling it out for residents whose religion has not been recognized. It is this "unrecognized religion" issue that is being requested to be canceled.

Based on the request, through decision Number 97 / PUU-XIV / 2016, the Constitutional Court granted all requests. This decision can be said to be an important breakthrough regarding the status of believers who have been discriminated against.

This decision can be seen as a continuation of the Court's opinion in the previous decision. In Decision Number 19 / PUU-VI / 2008, related to judicial review of the Law on Religious Courts, the Constitutional Court put a view on the understanding of the Indonesian state regarding the relationship between religion and the State. The Constitutional Court emphasized that Indonesia is not a religious state based only on one particular religion. However, Indonesia is also not a secular state which does not pay attention to religion at all and leaves religious matters completely to individuals and society.

The Constitutional Court further emphasized that the right to religion and belief includes the right to believe in God Almighty and the right to obtain public services. The right to adhere to a religion or belief in God Almighty is a constitutional right of citizens, not a gift from the State. This right stems from the conception of natural rights. In a democratic country, the state exists and is formed to protect, respect and fulfill these rights as referred to in Article 28E paragraph (1) and (2), Article 29 paragraph (2) of the 1945 Constitution.

In relation to Article $28 \mathrm{E}$ paragraph (1) and 
(2) and Article 29 paragraph (2), religion is always related to belief, where religion is a belief itself. However, according to the Constitutional Court, by reading and understanding the existence of Article 28E paragraphs (1) and (2) of the 1945 Constitution, religion and belief are very likely to be understood as two different things, and both of them are equally recognized for their existence. This interpretation of the Constitutional Court appears because textually Article $28 \mathrm{E}$ paragraph (1) talks about "the right to religion and worship according to religion", while Article $28 \mathrm{E}$ paragraph (2) regulates the right to freedom of belief. The Constitutional Court also interprets, by using the conjunction "and" in the phrase: "... and to worship according to their religion and belief" in Article 29 of the 1945 Constitution, placing the matter of "belief" in proportion to "religion". ${ }^{3}$ By placing the rules of religion and belief in two different norms, the 1945 Constitution basically also places belief differently from religion.

According to the Constitutional Court, the formulation of norms in Article 61 paragraph (1) and paragraph (2) as well as Article 64 paragraph (1) and paragraph (5) of the Population Administration Law means that the Law constructs the right or freedom to practice religion, which actually includes belief in God Who Almighty, as a gift from the State. In fact, the right or freedom to practice religion (including belief in God Almighty) is a right inherent in everyone, because these rights are derived from natural rights, not gifts from the state. Because the right to have religion and belief is one of the most basic human rights, it has the consequence of the State's responsibility to ensure that the human rights of its citizens are actually enjoyed in practice..$^{14}$

\section{2) The Blasphemy Law}

The blasphemy law in Indonesia is regulated in two laws, namely Law no. 1 / PNPS / 1965 concerning the Prevention of Abuse and / or Blasphemy of Religion (hereinafter referred to as the Blasphemy Law) and Article 156a of the

${ }^{13}$ See the verdict of Constitutional Court Number 97/ PUU-XIV/2016, pp. 140-141

${ }^{14}$ See the verdict of Constitutional Court Number 97/ PUU-XIV/2016, pp. 148-153.
Criminal Code. ${ }^{15}$ This law is viewed as one of the points that fostered intolerance towards minority groups after the New Order. ${ }^{16}$ The Law on Blasphemy of Religion was tested twice by the Court. The first material test was conducted in 2009 a number of activists for freedom of religion and belief; and secondly, in 2012, several Shiites, Tajul Muluk et al. were "victims" of the Blasphemy Law.

In the first judicial review the petitioner argued that all articles in the Blasphemy Law were against human rights as guaranteed in Article 28 of the 1945 Constitution. Throughout the trial, in front of the Constitutional Court, demonstrations were filled with demonstrations from those who refused to cancel the law. The parties that submitted the judicial review, starting from legal advisors, expert witnesses and so on, were subjected to tremendous pressure and intimidation.

Through decision No. 140 / PUU-VII / 2009 The Constitutional Court rejected all applications. The Constitutional Court stated that the Blasphemy Law was constitutional. Although the Blasphemy Law, drafted in an emergency situation in 1965 , is still considered relevant, it does not contradict the 1945 Constitution. The Constitutional Court believes that if the Blasphemy Law is repealed, social chaos will arise because there will be a legal vacuum. The Blasphemy Law is also considered to have nothing to do with religious freedom, but only to the blasphemy of religion. This law provides general protection and anticipation of conflicts in the midst of society.

The Constitutional Court assessed that the Blasphemy Law is formal, providing certainty that everyone is prohibited from disseminating and recommending interpretations of activities that deviate from the main principles of religious

${ }^{15}$ Article 156a of the Criminal Code is a mandate of Article 4 of Law no. 1 / PNPS / 1965 which states that in the KUHP there is a new article, namely Article 156 a which reads: "To be punished with imprisonment for a maximum of 5 years whoever deliberately in public expresses feelings or commits an act: $a$. which are principally hostile, abuse or desecration of a religion adhered to in Indonesia; $b$. with the intention so as not to adhere to any religion based on the One Godhead ".

${ }^{16}$ Noorhaidi Hasan, "Religious Diversity and Blasphemy Law Understanding Growing Religious Conflict and Intolerance in Post-Soeharto Indonesia", al-Jamiah Journal of Islamic Studies, vol. 55, no. 1 (2017), pp. 105-126. 
teachings. The argument of the Constitutional Court is not only related to the constitution, but also to sociological-political considerations. This is evident in the argument of the Constitutional Court which states that if this law is repealed there will be chaos, unrest, division and public hostility because of the vacuum of the law. ${ }^{17}$

Here, the Constitutional Court interprets the precepts of the Supreme Lordship with the state's ability to make legislation to intervene in the religious beliefs of its citizens if it is deemed that these beliefs are deemed unbelieving in one God. This Constitutional Court decision provides a legal way for the state to intervene in the lives of religious communities not only in relation to the external forum, namely areas where other parties can intervene, but also the forum internum, namely areas where other parties should not be able to intervene, based on Article 28J. UUD 1945.

Two years after the Constitutional Court issued a decision, the Blasphemy Law of the Criminal Code was again tested for its constitutionality. Different from before. This time, the Blasphemy Law and Article 156a of the Criminal Code are considered to be contradicting Article 28D of the 1945 Constitution, which reads: "Everyone has the right to recognition, guarantees, protection and legal certainty that is just and equal treatment before the law".

Although the applicant for the judicial review developed the argument that the Blasphemy Law and Article 156a of the Criminal Code contained many problems because the norms created legal uncertainty, the Constitutional Court still rejected the petition. In Decision Number 84 / PUU-X / 2012, there is actually no new argument from the previous decision. In this decision the arguments put forward in decision No. 140 / PUU-VII / 2009 that Indonesia as a country that adheres to religious beliefs is not separated from the state, has a Ministry of Religion that serves and protects the growth and development of religion.

${ }^{17}$ See the verdict of Constitutional Court Number 140/ PUU-VII/2009, p. 287.

\section{3) Application of Islamic Criminal Law through Religious Courts}

The desire to apply Islamic criminal law was one of the central issues since the early days of Indonesian independence. Unlike Islamic civil law, the Indonesian government does not provide enough room for the implementation of Islamic penalties. Feeling that the State has not been facilitated by the implementation of Islamic criminal law, a citizen named Suryani who is located in Serang Banten filed a judicial review of the law. no. 3 of 2006 concerning Religious Courts. ${ }^{18} \mathrm{He}$ challenged Article 49 paragraph (1) where Islamic criminal law is not part of the competence of the Religious Courts.

According to the Petitioner, Islamic law with all of its branches including Islamic criminal law must be enforced in Indonesia because Indonesia is a country based on One Godhead. For this reason, Suryani asked for the revocation of Article 49 paragraph (1) of the Law on the Religious Courts. ${ }^{19}$

The Petitioners argued that the implementation of Article 49 paragraph (1) has impaired their constitutional rights to implement Islamic law. Islamic Criminal Law is a unit of Islamic law whose implementation must also be facilitated by the State. This article is deemed contrary to Article $28 \mathrm{E}$ paragraph (1), Article $28 \mathrm{I}$ paragraph (1) and (2), as well as Article 29 paragraph (1) and (2) of the 1945 Constitution.

The Constitutional Court rejected the petition, the arguments presented were considered legally groundless. Article 49 paragraph (1) of the Law on Religious Courts is declared not to contradict the constitution. In Decision No. 19 / PUU-VI / 2008, the Constitutional Court stated: first, the Constitutional Court has no authority to increase the absolute competence of the Religious Courts as stipulated in Article 49 paragraph (1) of the Law on Religious Courts, because the Constitutional Court only has the authority to examine the constitutionality of laws and can only act as negative legislators,

${ }^{18}$ Law No. 3 of 2006 is an improvement from Law no. 7 of 1989 concerning Religious Courts.

${ }^{19}$ Article 49 paragraph (1) states that the Religious Courts have the authority to examine, to decide and to settle cases among Muslims related to marriage, inheritance, wills, grants, waqf, grants, sodaqah and sharia economics. 
not authorized to add regulatory norms (positive legislators).

Second, the request to include Islamic criminal law in the authority of the Religious Courts is not in accordance with the Indonesian state understanding of the relationship between the state and religion. The Constitutional Court stated that Indonesia is not a religious country based only on one religion, but Indonesia is also not a secular country that does not pay attention to religious matters.

Third, the provisions of Article 49 paragraph (1) of the Law on Religious Courts in no way reduce the Petitioner's rights and freedom to embrace a religion and worship according to his religion as guaranteed in Article 28E paragraph (1), Article 281 paragraph (1) and (2), as well as Article 29 paragraph (2) of the 1945 Constitution.

This argument shows the ideological-political position of the Constitutional Court regarding the position of Islamic criminal law, namely the disapproval of the existence of a special criminal law for Muslims. This is where the tolerance limit for the application of Islamic law through the State. This attitude is different from Islamic civil law, which has almost all become part of State law.

\section{Marriage Law}

\section{1) Polygamy Arrangements}

In the Marriage Law, the regulation on polygamy is regulated in Article 3 paragraph (1) and paragraph (2); Article 4 paragraph (1) and (2); Article 5 paragraph (1); Article 9; Article 15; and Article 24. The constitutionality of these articles is tested by $\mathrm{M}$. Insa, $\mathrm{SH}$, a resident whose address is in Bintaro, South Jakarta, because they are considered to have taken away the freedom of the right to religion and belief, which is guaranteed in Article 29 paragraph (1) and paragraph (2). ; and also Article 28B paragraph (1); Article 28E Paragraph (1); Article 28I paragraph (1) and (2) of the 1945 Constitution. These articles of the constitution are related to the guarantee of human rights to practice religion and belief. For the petitioner, polygamy is part of the Islamic law and has the value of worship. The Petitioner feels aggrieved by the articles in the Marriage Law that regulate polygamy. With this arrangement, his religious right to worship is lost. Because of that, the petitioner asked the Constitutional Court to cancel the articles that limit and regulate polygamy.

Article 3 Paragraph (1) and (2) of the Marriage Law basically states that a man can only have one wife, and a woman can only have one husband. However, the court can give permission for a husband to have more than one wife if he wants. Thus, this article regulates that a husband who wants polygamy must obtain permission from the court (Article 4 paragraph [1]). The court only gives permission if: a) the wife is unable to carry out her obligations as wife; b) the wife has physical disabilities and incurable diseases; c) the wife cannot give birth to offspring (Article 4 Paragraph 2). In Article 5 Paragraph (1), a number of requirements are added to apply to the court, namely: a) the consent of the wife; b) assurance that husbands can provide for the necessities of life of their wives and children; c) guarantee that the husband can do justice.

Meanwhile Articles 15 and 24 of the Marriage Law regulate those who are still bound by marriage to prevent new marriages and are allowed to cancel marriages where one of the parties is still bound by the other. These provisions are seen as an obstacle to the fulfillment of human rights, especially in relation to the right to worship and practice religion and belief.

The Constitutional Court's decision is based on arguments: first, the provisions governing polygamy for citizens whose religious laws allow polygamy is reasonable, because marriage is valid according to Article 2 Paragraph (1) of the Marriage Law if it is carried out in accordance with their religion and belief. On the other hand, it is unnatural if the Marriage Law regulates polygamy for those whose religious laws do not recognize polygamy. So this arrangement is not discrimination, because in this arrangement nothing is differentiated, but rather regulates according to what is needed.

Second, the articles contained in the Marriage Law which contain the reasons, conditions and procedures for polygamy, are to ensure that the rights of wives and prospective wives are fulfilled which are the obligations of husbands who are polygamous in order to achieve the goal of marriage. Thus, this regulation cannot be 
interpreted as nullifying the provisions that allow polygamous marriage.

\section{2) Status of Children Born Out of Legal Marriage}

Provisions regarding the legal status of children born out of legal wedlock, namely Article 2 Paragraph (2) and Article 43 Paragraph (1) of the Marriage Law were questioned by Machica Mochtar (MM), a singing artist, and her son Muhammad Iqbal Ramadhan ( MIR). MIR was a child from a marriage that was not registered or commonly called a sirri marriage - MM with Moerdiono, the Minister of State Secretary during the New Order era. However, until Moerdiono died in 2011, he never recognized MIR as his son. MIR also only has a civil relationship with his mother. The norms that MM challenged were Article 2 Paragraph (2) and Article 43 Paragraph (1) of the Marriage Law. MM feels that his constitutional rights have been impaired by these articles.

Article 2 Paragraph (2) of the Marriage Law states, "Every marriage is recorded according to the prevailing laws and regulations". This Article, according to the Petitioner, is detrimental to his constitutional rights which have been guaranteed in the 1945 Constitution Article 28B Paragraph (1) and Paragraph (2), Article 28D Paragraph (1). The articles that are used as the touchstone are articles that guarantee human rights, especially the right to form a family and continue offspring through a legal marriage; children also have the right to live, grow and develop and have the right to protection from violence and discrimination. According to the Petitioner, the constitution has guaranteed everyone has the right to carry out a marriage as long as it is in accordance with their religion and belief. In this regard, the applicant has carried out a marriage in accordance with Islamic religious norms. The norms contained in Article 2 Paragraph (2), according to the applicant, have reduced religious norms, so that the existence of a marriage which he undertakes according to Islamic law is not recognized because it is not recorded. Due to the reduction of religious norms by legal norms, not only does the applicant's marital status become unclear, but also results in the status of the child resulting from the marriage. This is as stated in Article 43 Paragraph (1) of the Marriage Law which states that children born outside of marriage only have a civil relationship with their mother and their mother's family. Based on this article, the applicant's child only has a civil relationship with his mother. This is considered unfair because the applicant has entered into a marriage that is legal according to Islam. In its decision, the Constitutional Court accepted some of the requests. In relation to Article 2 Paragraph (2) which regulates marriage registration, the Constitutional Court rejected the petition. This means, the Constitutional Court is of the opinion that marriage registration is not against the constitution and cannot be viewed as a reduction of religious norms by legal norms. By citing the General Elucidation of Law no. 1 of 1974, the Constitutional Court was of the opinion that marriage registration was not a factor determining the legal requirements of a marriage. Marriage registration is an administrative obligation which is required based on statutory regulations. From the State side, marriage registration is important for upholding the State's function to guarantee the protection, advancement, enforcement and fulfillment of human rights. Meanwhile, from the community side, marriage is a legal act which has implications for the occurrence of broad legal consequences. Therefore the State must protect and serve the rights arising from this marriage.

In relation to Article 43 Paragraph (1), the Constitutional Court stated that this article is contrary to the 1945 Constitution as long as it is interpreted as eliminating civil relations with men which can be proven based on science and technology as a biological father. Therefore, Article 43 Paragraph (2) must be read, "Children born outside of marriage have a civil relationship with their mother and mother's family as well as with a man as their father which can be proven based on science and technology and / or other evidence according to law. have a blood relationship, including a civil relationship with his father's family.

The legal issue of the status of children born outside of marriage is the legal meaning of the phrase "born outside of marriage". Naturally, it is impossible for a woman to become pregnant without the meeting between the ovum and spermatozoa. Therefore, according to the 
Constitutional Court, it is neither right nor fair if the law stipulates that a child born from a pregnancy due to sexual relations outside of marriage only has a relationship with his mother. It would be unfair if the law freed the man who fertilized and caused the child to be born from responsibility and negated the rights of the child.

On that basis, the relationship between the child and the father is not solely due to the existence of a marriage bond, but can also be based on evidence of the relationship between the child's blood and the father. Thus, apart from the matter of marriage administration, children born must receive legal protection. If not, the loser is a child born out of wedlock, even though birth was not his will. The law must provide just protection and certainty for the status of a child. ${ }^{20}$

\section{3) Marriage with Different Religions}

Four legal consultants in Jakarta, Damien Agata Yuvens, Rangga Sujud Widigda, Anbar Jayadi, and Luthfi Sahputra submitted a material review on religious marriage arrangements. The norm being tested is Article 2 Paragraph (1) of the Marriage Law which reads: "Marriage is legal if it is carried out according to that religion and belief". According to the Petitioner, there are 2 (two) levels of understanding of this norm, namely: 1) the validity of marriage which is stipulated by national law based on the laws of each religion; 2) the assessment of the validity of marriage is carried out by the respective laws of religion and belief. The two levels are basically one unit, where religious law has "changed clothes" to become State law.

A further implication is that marriages that are conducted outside the State's interpretation of each religion are not valid. In other words, the State forces every citizen to comply with one interpretation adopted by the State for each religion / belief. This arrangement, according to the petitioner, causes legal uncertainty for people intending to get married, which results in violations of the religious rights guaranteed through Article 28B Paragraph (1), Article 28E Paragraph (1 and 2),

${ }^{20}$ See the verdict of Constitutional Court Number $46 /$ PUU-VIII/2010 especially the opinion of the Court
Article 28I Paragraph (1) and Article 29 Paragraph (2) of the 1945 Constitution.

In this regard, the petitioner asked the Constitutional Court that the norms in Article 2 Paragraph (1) of the Marriage Law be declared contrary to the 1945 Constitution and do not have binding legal force as long as it is not interpreted, the interpretation of the law of religion and belief is left to the respective prospective bride and groom.

The application is divided into two parts, namely the reasons for the material test and the reasons for the formal test. The reasons for the judicial review include, among other things, the judgment imposed by the State on its citizens who are married through Article 2 Paragraph (1) of the Marriage Law. This restriction is considered by the applicant to have violated the right to enter into a legal marriage and the right to form a family as guaranteed in Article 28B Paragraph (1) of the 1945 Constitution. Norms of Article 2 Paragraph (1) are also seen as opening up a very wide space for interpretation and causing conflicts between norms so that cannot guarantee the fulfillment of the right to just legal certainty as regulated in Article 28D Paragraph (1) of the 1945 Constitution.

Meanwhile, in a formal manner, the test is based on the reasons, the enforcement of Article 2 Paragraph (2) of the Marriage Law has resulted in various smuggling of laws in the marriage sector; these norms do not meet the standards as statutory regulations; and contrary to its own purpose, namely that every marriage be based on the laws of each religion and belief. ${ }^{21}$

The Constitutional Court decided to reject the petition in its entirety. The applicant's petition is deemed to have no legal reasons. This means that Article 2 Paragraph (1) remains valid and is declared not to contradict the constitution, as argued by the petitioner. The Constitutional Court's decision is based on several arguments. First, in relation to the petitioner's argument which states that his constitutional right to marry and form a family is violated by the provision of Article 2 Paragraph

${ }^{21}$ These reasons are described at length in the Principles of the Petition as outlined in the Decision Number 68/PUUXII/2014, p. 15-58. 
(1), according to the Constitutional Court it is not proven. According to the Court, in exercising their rights and freedoms, every citizen is obliged to comply with the restrictions stipulated by law as referred to in Article 28J of the 1945 Constitution.

Second, in relation to the petitioner's arguments, Article 2 Paragraph (1) of the Marriage Law forces every citizen to obey the laws of their respective religions and beliefs, not things that are against the constitution. According to the Court, marriage is one of the problem areas regulated in the legal system in Indonesia, so that all actions and actions taken by citizens must comply with statutory regulations.

Third, in relation to the petitioner's argument that argues that the right to freedom of religion is violated by the enactment of Article 2 Paragraph (1) because it is considered to confuse administrative provisions with the implementation of religious teachings, dictating religious interpretation, is also incorrect. According to the Constitutional Court, the State has an interest in ensuring the legal certainty of marriage ties. Therefore, marriage cannot be seen from the formal aspect only, but must be seen from the spiritual and social aspects. Religion determines the legality of marriage, while the State determines the legality administratif of the marriage. ${ }^{22}$

\section{Negotiating Accommodation Limits}

Based on the description in the previous section, it appears that the way the Constitutional Court's interpretation of the constitution and the way of looking at the problem is not always the same. The verdict on blasphemy of the Constitutional Court is very restrictive and takes into account aspects outside the constitution, but in judging the Marriage Law the Constitutional Court gave birth to a conservative tendency. Meanwhile, in the Islamic criminal verdict in the Law on Religious Courts, the Constitutional Court tends to avoid deepening the discourse of religious freedom with a formal argument that the Court does not have the authority. ${ }^{23}$

${ }^{22}$ Read the Opinion of the Court in the Constitutional Court Decision Number 68/PUU-XII/2014, p. 150-153.

${ }^{23}$ Ismail Hasani (editor), Dinamika Perlindungan Hak Konstitusional Warga, p. 319.
On that basis, it is understandable if Simon Butt concluded that the Constitutional Court's decision related to religious issues seemed ambiguous and inconsistent. ${ }^{24}$ Related to the Religious Courts where the Constitutional Court refused to give additional authority related to jinayah law on the grounds that the criminal law only applies to national law; Regarding the issue of polygamy and the Religious Courts the Constitutional Court has a clear and firm attitude, although it is recognized that Islamic law is one of the sources of the formulation of national law, its implementation through the authority of the State must be limited. In fact, with regard to Islamic criminality, although some Muslims believe that Islamic punishment is part of Islamic teachings, this teaching cannot be implemented and becomes state law. If it is related to polygamy and the implementation of Islamic criminal law, the Constitutional Court appears to be more secular by rejecting Islamic criminal law, however in cases of blasphemy law and interfaith marriage, the Constitutional Court decisions appear more religious and tend to be accommodative and defend religious interests.

This ruling shows that there is a negotiation on the limits of accommodation of religious law (Islam) in state law. Insofar as it is related to Islamic criminal matters, the Constitutional Court has made a kind of limit of accommodation of state law politics against religious law (Islam). With this perspective, the Constitutional Court tends to close the door on the possibility of a criminal law that specifically applies to Muslims nationally, let alone add the competence of the Religious Courts, although on a limited scale Islamic criminal law can be applied as in Aceh ${ }^{25}$ because of its specificity. ${ }^{26}$ The struggle for Islamic criminal law is not in making criminal law that applies exclusively to Muslims, but rather on legal politics including

${ }^{24}$ Simon Butt, "Between Control and Appeasement: Religion in Five Constitutional Court Decisions" in Tim Lindsey and Helen Pausacker (ed.), Religion, Law and Intolerance in Indonesia, (London: Rouledge, 2016), pp. 60-61.

${ }_{25}$ Aceh Qanun Number 6 of 2014 concerning Law of Jinayat and Qanun Number 7 of 2013 concerning Law of Jinayat Procedure.

${ }^{26}$ Aceh's specificity in implementing Islamic law is contained in Law no. 18 of 2001 concerning Special Autonomy for the Province of the Special Region of Aceh as Nanggroe Aceh Darussalam. 
aspects of Islamic crime in the national Criminal Code (KUHP).

Thus, there is no doubt about the existence of an exclusive Islamic criminal law as a ladder to become an Islamic state. The transformation of Islamic law into statutory regulations, especially related to criminal law, is more of a process of "Indonesianization" of criminal law, rather than the Islamization of national criminal law. ${ }^{27}$ This at the same time refutes the argument that the process of transforming Islamic law into statutory regulations is a ladder to an Islamic state. ${ }^{28}$ According to Arskal Salim, the process of transforming Islamic law is carried out through five levels which run hierarchically. First, Islamic law applies to areas of family law such as marriage, divorce and inheritance. Second, Islamic law applies to the economic and financial sectors such as Islamic banking and zakat. Third, Islamic law applies to religious ritual practices such as the obligation to wear the hijab for women or the legal prohibition of things that are contrary to Islamic teachings such as alcohol and gambling. Fourth, Islamic law also applies to the application of Islamic criminal law, especially with regard to the types of sanctions imposed on violators. Fifth, the use of Islam as the basis of the state and its government system.

From a hierarchical perspective, the higher the demands for the application of Islamic law, the closer to the Islamic state. With the same narrative, the 25th edition of the Weekly Gatra Magazine in May 2006 made a cover story entitled: "Negeri Syariah Is Just One Step". In this edition, it was reported that various movements made regulations with the nuances of Islamic law, both at regional and national levels, had brought Indonesia closer to becoming an Islamic state. However, after approximately fourteen years this concern was not proven. Even the spirit of implementing Islamic law in various regions can be said to be stagnant, if not said to have disappeared. Thus, the author

${ }^{27}$ Read Arskal Salim, Challenging the Secular State, The Islamization of Law in Modern Indonesia, (Honolulu: University of Hawai Press, 2009), p. 177.

${ }^{28}$ Arskal Salim, "Penerapan Syariat Islam Bukan Negara Islam?", published on http://islamlib.com/kajian/fikih/penerapansyariat-bukan-negara-islam/ on 23 March 2020. see Arskal Salim and Azyumardi Azra (Editor), Sharia and Politics in Modern Indonesia, (Singapore: ISEAS, 2003). agrees with Abdul Halim, ${ }^{29}$ who is of the opinion that the accommodation of Islamic law in national law does not necessarily bring Indonesia closer to an Islamic state because it is done within the legal framework and commitment to the Unitary State of the Republic of Indonesia based on Pancasila and the 1945 Constitution.

In contrast to Islamic criminal law where the Constitutional Court has clear negotiation boundaries, in the field of Islamic civil law, especially Islamic family law, there is no clear accommodation limit. Islamic civil law is not only fully accommodated in legal politics in Indonesia, but also confirmed by the Constitutional Court. Religious aspirations that tended to be conservative, such as the prohibition of interfaith marriage, polygamy and the age limit of marriage were strengthened by the Court. ${ }^{30}$ This conservatism can be understood as a reflection of the attitude of the religious community in general. Reform of the marriage law will always get strong reactions from religious circles. Because of this, the reform of the marriage law was limited.

The Constitutional Court's decision regarding family law which is quite progressive is only related to the status of children born outside of legal marriages. This has also received a strong reaction from Islamic circles who are considered permissive, even considered "legalizing" adultery. Chairman of the MUI, KH. Ma'ruf Amin said that the verdict was overdose and exceeded the limit and equated the child from adultery with the child born from a legal marriage. ${ }^{31}$ The General Chairperson of Muslimat NU, Khofifah Indarparawansa also commented that the Constitutional Court's decision could be problematic. ${ }^{32}$

${ }^{29}$ Abdul Halim, "Membangun Teori Politik Hukum Islam di Indonesia", Jurnal Ahkam, vol. XIII, no. 2 Juli (2013).

${ }^{30}$ Constitutional Court decision number 30-74/PUU-XII/2014

${ }^{31}$ See https://news.detik.com/berita/d-1866192/mui-nilaikeputusan-mk-soal-status-anak-di-luar-nikah-overdosis tertanggal 13 Maret 2012. Respond to the comments above, The Chief Justice of the Constitutional Court who decided the case, Mahfudh MD, commented that MUI did not understand the concept of law and rejected the Court's view of legalizing adultery. see https://news. detik.com/berita/d-1879155/soal-putusan-status-anak-di-luar-nikahketua-mk-nilai-mui-tak-paham, on 28 March 2012. To reduce the various negative responses, the Chief Justice of the Constitutional Court Mahfudh MD visited various Islamic boarding schools to explain the Constitutional Court's decision.

32 https://www.republika.co.id/berita/nasional/ umum/12/02/26/lzzyhr-muslimat-nu-putusan-mk-soal-anak-luarnikah-bisa-menjerumuskan, on February 26, 2012. 
As explained in the previous section, the Constitutional Court Decision states Article 43 paragraph (1) of Law no. 1 of 1974 concerning Marriage is considered unconstitutional and has no legal force if it removes the civil relationship with the biological father. So far, children born outside of legal marriages do not have any relationship with their biological father, even though their parents feel that they have entered into a legal marriage according to Islamic law (nikah sirri), even though it is not registered in the State administration. Thus, this Constitutional Court Ruling, on the one hand is quite progressive in terms of protecting children's rights, but on the other hand, this decision can be a means of protecting unregistered marriages..$^{33}$ However, the Constitutional Court refused if this decision was considered legal for adultery. The Constitutional Court's decision is clearly not related to the act of adultery, an act which is clearly prohibited by religion, but focuses on the rights of the born child. From this perspective, the Constitutional Court's decision is quite courageous amidst conservatism in Indonesia that continues to strengthen. ${ }^{34}$ The Constitutional Court dared to move out of the rigidity of legal positivism towards more substantial protection of human rights. ${ }^{35}$

Likewise with the decision regarding the religion column in the KTP for worshipers. This decision can be said to be a very important breakthrough in managing the relationship between religion and the State, especially for religious believers who so far feel that they are not fully recognized as citizens. ${ }^{36}$ They are always seen as "the other" who have no religion, and some even consider them a heretical group. The existence of a political confession of religion,

33 Positive and negative impacts of the Constitutional Court Decision, read Busman Edyar, "Status Anak Luar NikahMenurut Hukum Positif dan Hukum Islam Pasca Keluarnya Putusan MK Tentang Uji Materiil Undang Undang Perkawinan", al-Istinbath Jurnal Hukum Islam, vol. 1, no. 2 (2016), pp. 181-208

${ }^{34}$ Regarding the strengthening of conservatism, read Martin van Bruinessen (Ed.), Contemporary Developments in Indonesian Islam, (Singapore, ISEAS, 2013).

${ }^{35}$ See Habib Shulton Asnawi, "Politik Hukum Putusan MK No. 46/PUU-VIII/2010 tentang Status Anak di Luar Nikah: Upaya Membongkar Positivisme Hukum menuju Perlindungan HAM" dalam Jurnal Konstitusi, vol.10 no. 2 Juni (2013).

${ }^{36}$ Based on the records of the Ministry of Education and Culture in 2017, there were 187 communities of Beliefs. keeps them excluded. With the Constitutional Court ruling, the state's service to worshipers was getting better. In addition to being able to list as believers in the KTP religion column, the children of the devotees receive a guarantee of religious education in schools through the Minister of Education and Culture Regulation Number 27 of 2016 concerning Education Services to God Almighty in the Education Unit.

This shows that the position of religion in all its aspects within the State of Indonesia will always be an arena for contestation. ${ }^{37}$ In this contestation, Indonesian legal politics through the Constitutional Court continued to apply the principle of limiting the implementation of religious teachings. In the case of polygamy, the Constitutional Court confirmed the limitation of polygamy through administrative regulations. Likewise, the Constitutional Court's decision which strengthens the Law on Religious Courts which only resolves matters of marriage, inheritance, waqf and sharia economic disputes, does not include Islamic penalties, showing that there are such restrictions. However, in relation to the regulation on blasphemy and the prohibition of interfaith marriage, the Constitutional Court actually reinforced religious views. There is no definite formula for which aspects of religion can be included in State regulations, and which are not allowed, except for the impossibility of the existence of Islamic criminal law that applies specifically to Muslims. This will always create contestation between the various socio-political forces and the political direction of Indonesian law. The implication is that the contestation and negotiation of the State, religion and Human Rights will continue to occur in the future, especially efforts to influence the national criminal law by incorporating aspects of Islamic criminal law..$^{38}$ The limits of state accommodation on religious aspirations will continue to be contested. Although there will be more and more religious aspects accommodated in the laws and regulations, this does not necessarily lead to Indonesia becoming

${ }^{37}$ Read Simon Butt, "Islam, the State and the Constitutional Court in Indonesia", in Pacific Rim Law and Policy Journal, (2010), pp. 279-301.

${ }^{38}$ Read Simon Butt, "Islam, the State and the Constitutional Court in Indonesia", in Pacific Rim Law and Policy Journal, (2010), p. 279-301. 
a religious state, an Islamic state as previously mentioned.

\section{Conclusion}

Based on this description, it can be concluded that the issue of the relation between religion and state in Indonesia is an open space that will continue to contest. Religious aspirations will continue to be pushed into state regulations, both through the process of formulating statutory regulations, as well as judicial reviews in the Constitutional Court. The contestation can take place in society, in the parliamentary room or in the court room. Judicial review of a number of laws related to religious issues in the Constitutional Court is a space for contestation as well as negotiating various constitutional interests that are disturbed by the law. The Constitutional Court as the guardian of the constitution whose decisions are final and binding will give direction to how religious issues are put in the statutory legal system. This is the space for contestation and negotiation of various constitutional interests.

The study above shows that basically the Constitutional Court is accommodating with religious regulations even though there is a maximum limit, namely the accommodation of Islamic criminal law which is exclusive to Muslims. Regarding Islamic private-civil law, the Constitutional Court is very accommodating, tends to be conservative even though there are limited reforms. The Constitutional Court's decision regarding the status of children born out of legal wedlock is a form of this limited renewal. Although the verdict regarding the blasphemy offense can be said to be conservative, the status of followers of the Belief in God Almighty is an important legal breakthrough to eradicate discrimination based on religion and belief.

With this fact, there are at least two important things related to state accommodation towards religious regulations, especially Islam. First, with regard to Islamic private or civil law, the Constitutional Court opened a fairly wide accommodation space, so that more religious aspects would be accommodated by the state even with limited reform. Therefore, the theory of state accommodation towards religion needs a more detailed explanation, because many countries accommodate religious aspirations, but the level of accommodation varies. Even though it is not a religious state, the level of accommodation towards religion has deepened, although this cannot be interpreted by Indonesia as becoming a religious state. Second, the limit of accommodation is Islamic criminal law which cannot be made exclusively for Muslims even though it is possible in Islamic civil law. The accommodation of Islamic criminal law is only possible if the norms are incorporated into the national criminal law through a process of rational objectification.

\section{References}

Asshiddiqie, Jimly, Konstitusi dan Konstitusionalisme Indonesia, 2010, Jakarta: Sinar Grafika, 2010.

Bruinessen, Martin van (Ed.), Contemporary Developments in Indonesian Islam, Singapore, ISEAS, 2013.

Butt, Simon, "Judicial Review in Indonesia: Between Civil Law and Accountability? A Study of Constitutional Court Decisions 2003-2005", PhD Dissertation, Law Faculty, Melbourne Uiniversity, 2007.

Butt, Simon "Islam, the State and the Constitutional Court in Indonesia", dalam Pacific Rim Law and Policy Journal, 2010.

Cristina R, Dri Utari dan Ismail Hasani (Ed), Masa Depan Mahkamah Konstitusi: Naskah Konferensi Mahkamah Konstitusi dan Pemajuan Hak Konstitusional Warga, Jakarta: Pustaka Masyarakat Setara, 2013.

Edyar, Busman, "Status Anak Luar NikahMenurut Hukum Positif dan Hukum Islam Pasca Keluarnya Putusan MK Tentang Uji Materiil Undang Undang Perkawinan", al-Istinbath Jurnal Hukum Islam, vol. 1, no. 2, 2016

Efendy, Bahtiar, Islam dan Negara: Transformasi Pemikiran dan Praktik Politik Islam di Indonesia, Jakarta: Paramadina, 1998.

Hasan, Noorhaidi, "Religious Diversity and Blasphemy Law Understanding Growing Religious Conflict and Intolerance in PostSoeharto Indonesia", al-Jamiah Journal of Islamic Studies, vol. 55, no. 1, 2017.

Hasani, Ismail (editor), Dinamika Perlindungan Hak Konstitusional Warga, Mahkamah Konstitusi sebagai Mekanisme Nasional Baru Pemajuan 
dan Perlindungan Hak Asasi Manusia, Jakarta:

Pustaka Masyarakat Setara, 2013.

Hirschl, Ran, Contitutionalism Theocracy, Harvard: Harvard University Press, 2010.

Jurnal Konstitusi Volume 10 No. 2, Juni 2013.

Jurnal Konstitusi Volume 10 No. 4 Desember 2013. Jurnal Konstitusi Volume 10 No. 2, Juni 2013.

Lindsey, Timothy dan Simon Butt, The Indonesian Constitution: A Contextual Analysis, Oxford: Hard, 2012.

Tim Lindsey and Helen Pausacker (ed.), Religion, Law and Intolerance in Indonesia, London: Rouledge, 2016.

Littlejohn, Stehpen, Theories of Human Communication, Calofornia: Wadsworth Publishing Company, 1989

Mahfud MD, Moh., Politik Hukum di Indonesia, Jakarta: RajaGrafindo Persada, 2012 , Membangun Politik Hukum, Menegakkan Konstitusi, Jakarta: Rajawali Pers, 2011

Mahkamah Konstitusi, Laporan Kinerja Mahkamah Konstitusi Tahun 2014.

Menchik, Jeremy, Islam and Democracy in Indonesia, Tolerance without Liberalism, Cambridge: Cambridge University Press, 2016. Putusan Mahkamah Konstitusi Nomor 97/PUUXIV/2016.
Putusan Mahkamah Konstitusi Nomor 68/PUUXII/2014.

Putusan Mahkamah Konstitusi Nomor 84/ PUU-X/2012.

Putusan Mahkamah Konstitusi Nomor 46/PUUVIII/2010.

Putusan Mahkamah Konstitusi Nomor 140/PUUVII/2009.

Putusan Mahkamah Konstitusi Nomor 19/PUU$\mathrm{VI} / 2008$.

Putusan Mahkamah Konstitusi Nomor 12/ PUU-V/2007.

Rambe, Mara Sutan "Proses Akomodasi Hukum Islam Ke Dalam Hukum Pidana Nasional", Jurnal Cita Hukum, vol. 3 no. 2, 2015.

Sidharta, Hukum Penalaran dan Penalaran Hukum, Jakarta: Genta Publishing, 2013.

Stockman, Petra, The Indonesian Constitutional Court: A Study into Its Beginning and First Years of Work, Jakarta: Hans Seidel Foundation, 2007.

UU No. 24 Tahun 2003 tentang Mahkamah Konstitusi.

https://nasional.tempo.co/read/793197/sekolahberkukuh-siswa-penghayat-kepercayaan-taknaik-kelas 